DIW BERLIN

Discussion

Papers
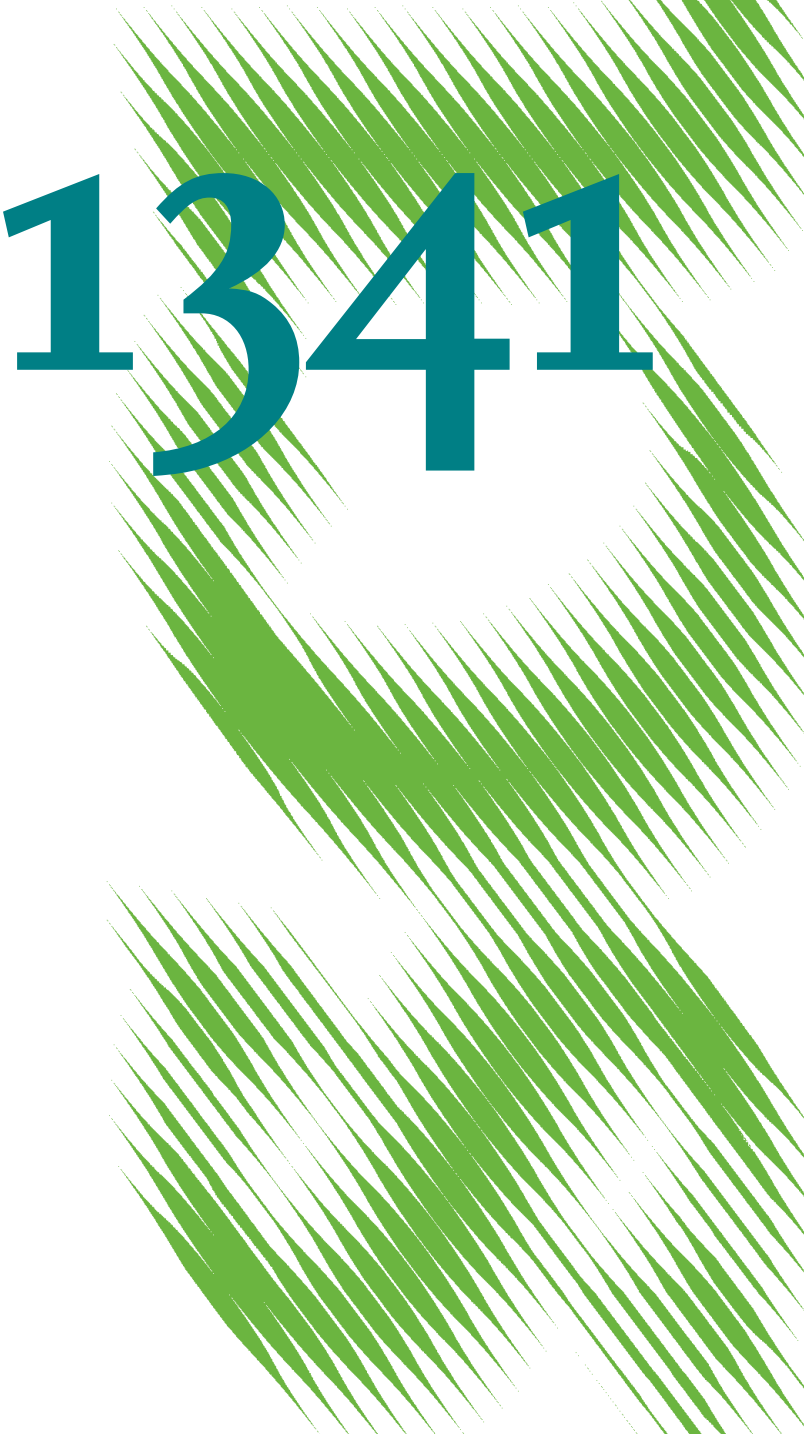

1

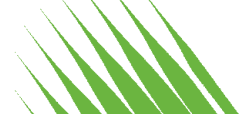

MIMMMMMMMM

Understanding Chinese Consumption: The Impact of Hukou 
Opinions expressed in this paper are those of the author(s) and do not necessarily reflect views of the institute.

IMPRESSUM

(C) DIW Berlin, 2013

DIW Berlin

German Institute for Economic Research

Mohrenstr. 58

10117 Berlin

Tel. $+49(30) 89789-0$

Fax +49 (30) $89789-200$

http://www.diw.de

ISSN print edition $1433-0210$

ISSN electronic edition 1619-4535

Papers can be downloaded free of charge from the DIW Berlin website:

http://www.diw.de/discussionpapers

Discussion Papers of DIW Berlin are indexed in RePEc and SSRN:

http://ideas.repec.org/s/diw/diwwpp.html

http://www.ssrn.com/link/DIW-Berlin-German-Inst-Econ-Res.html 


\title{
Understanding Chinese Consumption: The Impact of Hukou
}

\author{
Christian Dreger \\ Tongsan Wang \\ Yanqun Zhang ${ }^{1}$
}

\begin{abstract}
The Chinese growth miracle was based on exports and investment in recent years. While strong output growth has been maintained even during the financial crisis, the imbalances within the country increased. To return to a more sustainable path of development, policies are directed to improve the role of private consumption. However, the institutional framework is an impediment to the transformation, as it weakens the incentives of households to consume. Besides a low degree of social security and highly regulated financial markets, we stress the relevance of the hukou system as the main driver for modest consumption, especially in recent years. After controlling for different income levels, the average propensity to consume is significantly lower for migrants, as their access to public services is limited. The downward pressure on consumption will increase in the future. The urbanization strategy of the government will likely raise the number of migrants with limited hukou rights, if it is not accompanied by respective reforms. Therefore, the transformation towards consumption driven growth is endangered without further reforms.
\end{abstract}

Keywords: Chinese private consumption, urbanization strategy, hukou system

JEL: E21, O15, R23

\footnotetext{
${ }^{1}$ Dreger: German Institute for Economic Research (DIW Berlin), European University Viadrina Frankfurt Oder, email: cdreger@diw.de, Wang: Chinese Academy of Social Sciences (CASS), Beijing, email: wangts@cass.org.cn, Zhang: Chinese Academy of Social Sciences (CASS), Beijing, China, email: yqzhang@cass.org.cn. Yanqun Zhang thanks the innovation program of CASS for providing financial support.
} 

Over the last decades, China transformed from an agricultural country to the second largest economy in the world, with a share of 15 percent of global GDP in PPPs. This miracle with annual GDP growth rates of 10 percent on average poses serious risks to a smooth development of the global economy. High growth rates are likely non sustainable, as they are driven by rising imbalances. To avoid a slowdown caused by a fall in exports during the financial crisis, the Chinese government launched a huge fiscal package (Dreger and Zhang, 2011). State owned banks supported the stimulus, as access to credit has been improved for the state owned enterprises. As lending was often motivated by political rather than economic decisions, the amount of non performing loans might be substantial ${ }^{2}$. Government debt is on a rising trend, especially at the level of provinces. Prestigious investment projects have led to overcapacities in many areas.

-Figure 1 about here-

To return to a more sustainable path, forward looking policies should better address the imbalances. According to the new government, GDP growth should be based on private demand to a higher extent. In this strategy, consumption expenditures of private households play a crucial role. As export and investment growth outperformed the expansion of private consumption, the consumption share dropped to 35 percent of GDP, the lowest level compared to other East Asian countries (Figure 1). The bulk of the decline can be traced to the period after the turn of the century. According to the five year plan launched in 2011, faster urbanization will become the key pillar to promote the further transformation of the Chinese economy. In principle, this could stimulate private consumption, as cities provide a more favourable climate to consume than rural areas.

The reversal of the strategy from investment to consumption-led growth is unlikely to succeed without the implementation of structural reforms. The current institutional design serves as an obstacle to stronger consumption, as it promotes a further increase of the savings rate. Savings is already at record levels, partly because of a low level of social security combined with the one-child policy and credit constraints in highly regulated financial markets. The Chinese hukou

\footnotetext{
${ }^{2}$ In the years preceeding the financial crisis, banks made considerable progress in reducing the amount of bad loans, see Allen, Qian, Zhang and Zhao (2012).
} 
system of household registration is neglected in the debate. Migrants from rural to urban areas are often restricted to access public services. Hence, they have to save more of their income to assure against risks. Based on a large data set of urban households and migrants, this analysis provides evidence on the relevance of the hukou institution to explain lower consumption expenditures. The non-availability of hukou rights accounts for one half of the decline in the consumption ratio in the observation period. The urbanization strategy may intensify these trends, as it can raise the number of migrants with restricted hukou rights. To improve the conditions for consumption-led growth, the strategy should be accompanied by reforms in the household registration system.

In Section 2, the literature on private savings and consumption is reviewed. Basic principles of the hukou system and migration trends are discussed in Section 3. Section 4 describes the data and holds the empirical results on consumption behaviour of urban citizens and migrants. Finally, Section 5 provides some policy conclusions.

\section{Chinese consumption and savings behaviour}

High savings rates in East Asian countries are caused by cultural traditions like religious norms, self-discipline, and anti-extravagancy. Family ties are particularly strong, and families take social responsibilities to provide support for the elderly and bringing up children. However, even against this background, the Chinese savings rate is an exception. Overall savings rose from 37 to 53 percent of GDP over the last decade, the highest rate in the global economy (Ma and Yang, 2013). According to Yang (2012), the increase of household savings to 25 percent is the most important contributor to the evolution. As wages increased at higher rates than GDP over the same period, it is not linked to low income dynamics.

The rise in the household saving rate is difficult to reconcile with standard models of intertemporal consumption behaviour. When permanent income is high, households that smooth consumption should borrow against future income. This implies a hump-shaped profile of savings over the life cycle. Young workers save little (in anticipation of rising income), saving rates tend to peak when earnings are high (middle age) and fall as workers approach the retirement phase. In China, a $U$-shaped pattern of savings is observed instead, where especially the young and old cohorts save more (Chamon and Prasad, 2008). To understand savings behaviour of private households, the level of social security plays a crucial role. Past income gains have been often accompanied by higher uncertainty (Blanchard and Giavazzi, 2005). Households formerly 
covered by job security and cradle-to-grave benefits have lost old age provisions from state owned enterprises; i.e. the iron rice bowl. The one child policy reinforces the need for savings to cover expenses for health and retirement. Feng, He and Sato (2011) argued that the decline in the replacement ratio after the 1990s pension reform increased savings, especially for the young. Thus, the provision of broader social security might be seen as an instrument to reduce private saving rates. According to Barnett and Brooks (2010), an increase in public health expenditures can boost consumption, and the impact should be particularly visible in the urban areas of the country. Anyway, the reforms have been implemented around 1995 and may not fully explain the rise in the savings rate that occurred after the turn of the century. Wei and Zhang (2011) stressed that the increase in the savings rate is partially a result of the gender imbalances caused by the one child policy. The shrinking number of females relative to men fosters a more competitive marriage market. Therefore, parents of a boy save to increase the attractiveness of their son.

Other explanations refer to the presence of liquidity constraints in highly underdeveloped financial markets. The restrictions prevent agents from keeping the marginal utility of consumption constant, as they pose a bound on their possibilities to borrow against future income. As they cannot obtain sufficient credit from banks, households have to save for later purchases. This can be also observed in the Chinese housing market, where ownership becomes more important. Owners of poor-quality homes have higher savings rates than those with better homes, as they aim to buy better houses (Chamon and Prasad, 2010). A positive relationship between house prices and the savings rate has been reported by Wu and Xie (2013) for owners of less valuable properties. Because of the low interest rates on bank deposits, housing offers the most attractive return compared to other assets; see Fawley and Wen (2013). This can explain why most of the empty apartments in cities are already sold. In this vein, the Chinese housing boom reflects the desire of households to seek storages of wealth. There is also evidence for reversed causality, but the effects of housing prices on the savings rate seem to be rather modest (Wang and Wen, 2012).

Dissimilarities between urban and rural consumption behaviour have been stressed only in a few studies. Urban households account for 75 percent of aggregated private consumption. Cristadoro and Marconi (2011) argued that the rise in the savings rate due to precautionary behaviour, liquidity constraints, and insufficient social security is caused by urban, not by rural consumers. By analysing the effects of remittances on savings in rural areas, Zhu, Wu, Wang, Du and Cai (2011) concluded that migrants save less than rural non-migrants. Therefore, remit- 
tances are unlikely to improve capital accumulation needed for catching-up of the countryside. Chen, Lu and Zhong (2012) found that the marginal propensity to consume out of income of migrants without hukou rights is 30 percentage points lower than for urban residents. In fact, the distinction between consumption and savings of urban households, rural households and migrants is quite important for future growth perspectives. Differences are heavily shaped by the hukou institution.

\section{The hukou institution and urbanization trends}

The Chinese household registration (hukou) creates two different societies. Within each city, there are two groups of people: Urban residents who have local hukou, and migrants who do not. The former are favoured in resource allocation. See Naughton (2007) for a detailed discussion of the system. People without urban hukou are excluded from many public jobs and have limited access to social insurance and other welfare such as low rent housing. Children of migrants are often not allowed to enrol in public schools and live with their grandparents to attend school at their hometowns.

Initially the system has been established by the government after the communist revolution to control migration from the rural to urban areas (Cheng and Selden, 1994). Since then, barriers to migration have been gradually reduced to encourage higher rural mobility after the abolition of large and inefficient agricultural communes (Chan and Buckingham, 2008). Under the current setting, rural residents can register their temporary residency to legalize their work in cities. Furthermore, the inheritance of the hukou rights has broadened to allow succession through the lines of father and mother, which corrected the former disadvantage against rural women. But many Chinese still live outside their officially registered regions and under far less eligibility to public services. Past reforms replaced the old system of an agricultural and nonagricultural hukou with a status based on the location of permanent residence. Local governments obtained the control in deciding the levels of both hukou and non-hukou migration to their respective administrative jurisdictions, including the possibility of using permanent hukou rights as a way to raise fiscal revenues. ${ }^{3}$ Many cities received the right to define their own entry criteria. The new practice is directed towards rich people and might be irrelevant for ordinary peasants. Non-hukou holders are tolerated as temporary migrants; although many of

\footnotetext{
${ }^{3}$ Urban hukou is usually provided indirectly, where the practice differs across cities. For example, firms get hukou quota in Beijing, if their taxes exceed a certain level. People get a urban hukou in many cities if they buy a house.
} 
them are at their destination for years. The main incentive for governments to control the access to hukou is to limit expenditures on social security. Hence, the success of hukou reforms might depend on prior fiscal reforms, including a re-distribution of revenues between the local and central governments.

The Chinese transformation has been largely underpinned by huge shifts of labour from rural to urban areas. Since the onset of the economic reforms in 1978, the urban population increased by about 500 million people, while rural areas have lost 330 million citizens. Currently, 51 percent of the Chinese live in urban municipalities, compared to 18 percent at the onset of the reforms. At the same time, the share of urban residents with urban hukou has decreased. The evidence is not homogenous across regions, see Figure 2. In Beijing and Shanghai, 60 percent of the population possess urban hukou, after 70 percent in 2005 . The decline was more pronounced in special economic zones that have led economic growth. For example, the ratio fell to 20 percent in Shenzhen over the first two decades after the launch of the reforms ${ }^{4}$. In the absence of institutional change, stronger urbanization can reinforce this trend in the future, especially in large cities such as Beijing and Shanghai. Lower consumption of non-hukou households might impede the further transformation of the Chinese economy towards consumption led growth.

-Figure 2 about here-

\section{$4 \quad$ Hukou and consumption behaviour}

Evidence is based on a huge microeconomic dataset gathered by the Chinese Household Income Project (CHIP) in collaboration with the Chinese Academy of Social Sciences (CASS). The CHIP is designed and implemented to measure the distribution of income and related economic factors in urban and rural areas (Shi, 2009). Information includes the economic situation such as employment status, different sources of income, assets, consumption and sociodemographic characteristics like the family status, age, education and ethnicity. The CHIP provides distinct samples of urban households and migrants, selected from larger samples drawn by the

\footnotetext{
${ }^{4}$ Due to its close proximity to Hong Kong, the decline in the ratio started very early in Shenzhen. People who visited or lived in the city needed a special document issued by the Domestic Security Bureau at the beginning of the opening-up. This is the reason why rather long time series are available for this area. In later years, the regulation has been gradually relaxed.
} 
National Statistical Bureau. Due to data limitations, rural households are excluded from the analysis.

Data are collected through questionnaires in repeated cross sections at five year intervals. As no panel structure is provided, households cannot be linked over time. In the following, the last two waves are considered, i.e. 2002 and 2007. The 2002 survey is based on almost 7,000 urban and 2,000 migrant households. In the 2007 dataset, both types of households are equalIy represented $(5,000)$. Information is also available for individual household members. These data needs to be aggregated to the household level. Variables such as income are cumulated over household members. Sociodemographic variables are determined by the characteristics of the household head. A few variables need to be transformed in order to match the requirements of the study. Most important, remittances from migrants are reported as savings, but they are consumed by their families in the rural areas, at least in part. Therefore, they have been reallocated to increase consumption. The monetary value of gifts is treated in a similar fashion. Due to missing data, a small fraction of households (less than 3 percent) is excluded from further analysis.

An ordinary consumption function serves as a point of departure (Deaton and Muellbauer, 1999). Private consumption is explained by income and further variables describing the framework conditions under which the household operates. From the variety of characteristics, only the age profile, years of education, and the number of persons in the household appear to be significant (Table 1). Other candidates, like gender, family status, occupation, membership in the communist party, ownership of firms etc. can be safely ignored when explaining consumption behaviour. Due to the potential presence of outliers, quantile regression techniques are preferred. Specifically, the sum of absolute deviations from the median is minimized. The results show that income is by far the most important variable driving private consumption expenditures. The marginal propensity to consume (MPC) seems to be in a reasonable range. About 75 to 85 percent of additional income is spent for consumption. The MPC is higher for migrants, implying that the same income stimulus can generate larger expansionary effects for these households. The parameter has slightly decreased between 2002 and 2007, both for urban households and migrants. Probably, consumption adjusted only gradually to fast income growth.

In principle, the MPC should be lower for migrants, as they usually lack urban hukou rights. However, their lower income level can outperform the expected effect, see Table 2. According 
to the percentiles in the income distribution, both urban households and migrants experienced fast income growth over the 5-years period. Median income more than doubled for urbans (from 20,900 to 45,000 Yuan). The evolution is less pronounced at lower and stronger at higher quantiles, indicating that urban income became more concentrated. For example, income at the 0.9 quantile rose by 160 percent. Shifts in the income distribution have also contributed to the decline in the overall consumption ratio. Income growth has been especially pronounced for richer urban households, who have a lower propensity to consume. In contrast, income growth for migrants was less impressive: Annual median income rose from 14,300 to 20,400 Yuan. The 50 percent increase is representative for the whole distribution. ${ }^{5}$ Due to lower income growth, the relative position of migrants in the entire distribution worsened. While the median migrant worker received 68 percent of median urban income in 2002, the fraction fell to 45 percent in 2007.

-Table 1 and 2 about here-

Table 2 also shows the average propensity to consume (APC), i.e. private consumption divided by income. It is extracted from a regression of the APC on $(0,1)$ dummies for different income ranges. It can be seen that households with lower income have a higher APC ${ }^{6}$. This well established pattern from other countries holds also for the Chinese economy, for both urban households and migrants.

-Table 3 about here-

The comparison of the APC of urban households and migrants is blurred by different income levels. To isolate the effect of the hukou on consumption behaviour, households with similar income are compared by defining a low and a medium income range. High income households are excluded from the analysis, as they usually possess urban hukou rights. In the restricted

\footnotetext{
${ }^{5}$ The Gini coefficient of the income distribution rose from 0.310 (2002) to 0.373 (2007) for urbans, but has been rather stable for migrants $(0.337$ and 0.356$)$.

${ }^{6}$ Regression results are omitted to save space, but are available from the authors upon request. Note that this type of regression can also solve potential endogeneity problems, as income may not be considered as exogenous in a consumption regression.
} 
samples the APC is explained by a number of sociodemographic characteristics. The availability of urban hukou rights is modelled through a $(0,1)$ dummy that might affect the APC. Results are shown in Table 3.

\section{-Table 3 about here-}

The presence of urban hukou rights affects the APC, even after sociodemographic characteristics are taken into account. In the 2002 sample, households with urban hukou had an APC 5 or 6 percentage points higher than those without hukou ${ }^{7}$. This magnitude can be also detected in the 2007 survey, but only for medium incomes. At the lower end of the distribution, the hukou coefficient increases by 15 percentage points due to stronger migration in later years. Eventually, this pattern can be traced to the duration of the stay in urban areas, as incoming migrants may earn less than those who are living in the city since many years. The latter might be included in social networks which could provide better income opportunities. Overall, the results suggest that the removal of the hukou restrictions can boost private consumption substantially. The removal of the hukou restriction for the $\mathbf{2 6 0}$ million migrants could increase their APC by 10 percentage points on average. Consumption could rise by 2500 Yuan per household, implying an annual increase of 650 billion Yuan for the overall economy, i.e. 7 percent of the 2007 consumption level. The lack of hukou rights can explain about one half of the decline of the consumption ratio in the sample period. The other part might be related to a slight decrease of the propensity to consume and shifts in the income distribution in favour of high income households in urban areas.

\section{Conclusions}

The Chinese growth miracle was based on exports and investment in recent years. While strong output growth has been maintained even during the financial crisis, the imbalances within the country increased. To return to a more sustainable path of development, policies are directed to improve the role of private consumption. However, the institutional framework is an impediment to the transformation, as it weakens the incentives of households to con-

\footnotetext{
${ }^{7}$ Because of the inclusion of sociodemographic variables the mean of the APC cannot be inferred from the constant in the regressions.
} 
sume. Besides a low degree of social security and highly regulated financial markets, we stress the relevance of the hukou system as the main driver for modest consumption. After controlling for different income levels, the average propensity to consume is found to be substantially lower for migrants, because their access to public services is limited. This result can be detected especially at the low income range. The removal of the hukou restriction for the 260 million migrants would increase their APC by 10 percentage points on average. Consumption could be stimulated by 2,500 Yuan per household, implying an annual increase of 650 billion Yuan for the overall economy, i.e. a 7 percent of the consumption level in 2007. The lack of hukou rights can explain one half of the decline of the consumption ratio in the sample period. Other parts might be related to the slightly lower propensity to consume and shifts in the income distribution in favour of high income households. The downward pressure of the hukou restriction on private consumption expenditures will raise in the future, as the urbanization strategy of the government can likely increase the number of migrants with restricted hukou rights, if it is not accompanied by respective reforms. Therefore, the transformation towards consumption driven growth might be endangered. 


\section{References}

Allen F, Qian J, Zhang C, Zhao M (2012): China's financial system: Opportunities and challenges, NBER Working Paper 17828.

Barnett S, Brooks R (2010): China: Does government health and education spending boost consumption? IMF Working Paper WP/10/16.

Blanchard OJ, Giavazzi F (2005): Rebalancing growth in China: A three-handed approach, MIT Department of Economics, Working Paper 05-32.

Chamon M, Prasad E (2008): Why are saving rates of urban households in China rising? NBER Working Paper 14536.

Chamon M, Liu K, Prasad E (2010): Income uncertainty and household savings in China, IMF Working Paper WP/10/289.

Chan K W, Buckingham W (2008): Is China abolishing the hukou system? China Quarterly 195, $582-605$.

Chen B, Lu M, Zhong N (2012): Hukou and consumption heterogeneity, Hitotsubashi University, Global COE Hi-Stat Discussion Paper 221.

Cheng T, Selden M (1994): The origin and social consequences of China's hukou system, China Quarterly 139, 644-668.

Cristadoro R, Marconi D (2011): Households savings in China, Banca D'Italia, Working Paper 838.

Deaton A, Muellbauer J (1999): Economics and consumer behaviour, Cambridge University Press, Cambridge UK.

Fawley BW, Wen Y (2013): The great Chinese housing boom, Economic Synopses 13, Federal Reserve Bank of St. Louis.

Feng J, He L, Sato H (2011): Public pension and household saving: Evidence from China, Journal for Comparative Economics 39, 470-485.

Ma G, Yang DT (2013): China's high savings puzzle, IZA Discussion Paper 7223.

Naughton B (2007): The Chinese economy: Transitions and Growth, Cambridge, MA, MIT Press, Chapter 5: 113-136. 
Shi L (2009): Chinese Household Income Project 2002, Ann Arbor Michigan, doi: 10.3886/ICPSR 21741.v1.

Wang X, Wen Y (2012): Housing prices and the high Chinese saving rate puzzle, China Economic Review 23, 265-283.

Wei S-J, Zhang X (2011): The competitive saving motive: Evidence from rising sex ratios and savings rates in China, Journal of Political Economy 119, 511-564.

Wu B, Xie J (2013): House prices and households saving rate: Evidence from China, http:// ssrn.com/abstract=2261043 or http://dx.doi.org/10.2139/ssrn.2261043

Yang, DT (2012): Aggregate savings and external imbalances in China, Journal of Economic Perspectives $26,125-146$.

Zhu Y, Wu Z, Wang M, Du Y, Cai F (2011): Do migrants really save more? Understanding the impact of remittances of rural savings, Journal of Development Studies 48, 654-672. 
Figure 1: Private consumption in East Asian countries

Fraction of GDP

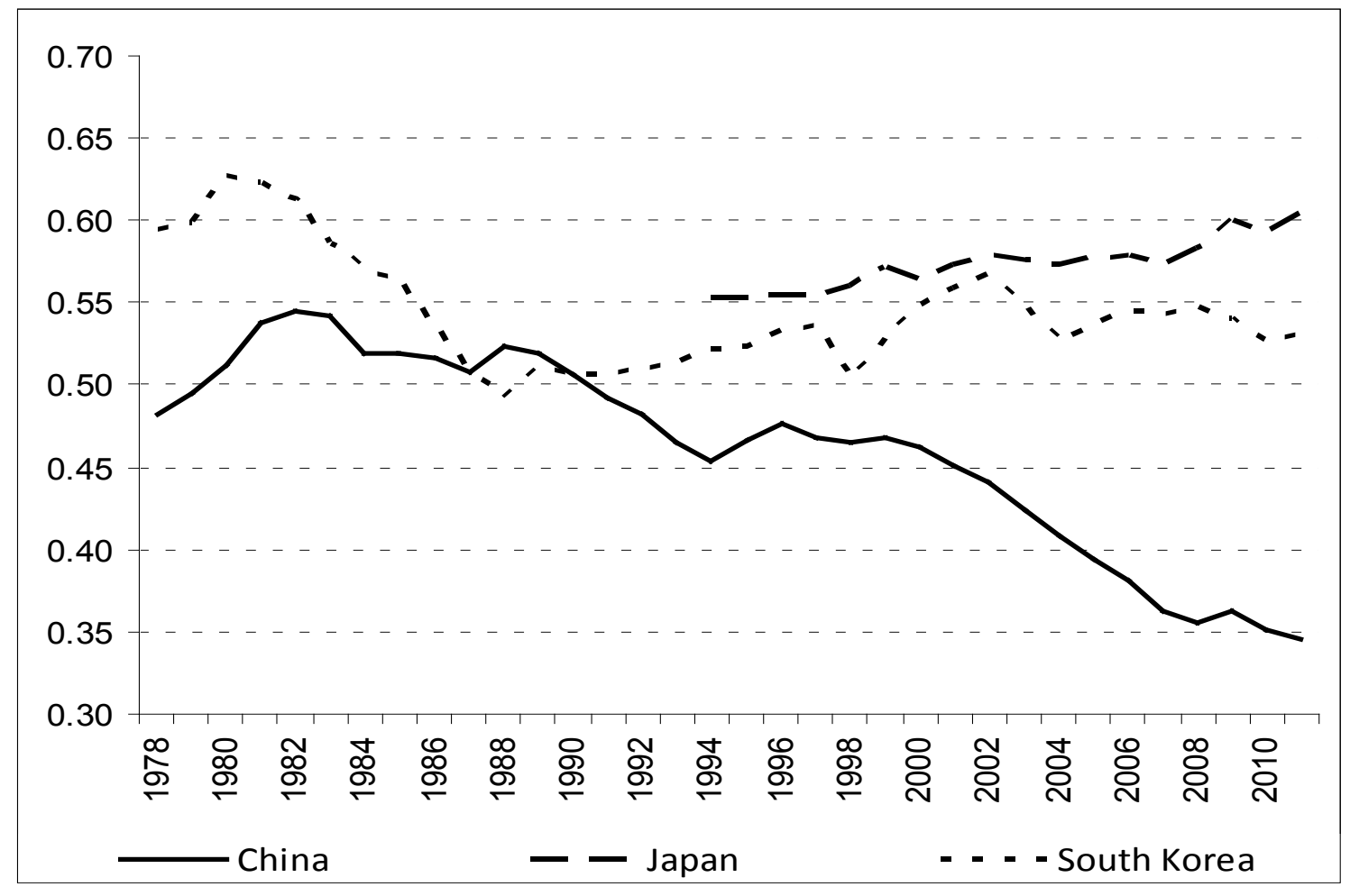

Source: OECD Main Economic Indicators 
Figure 2: Urban hukou holders as a share of urban population

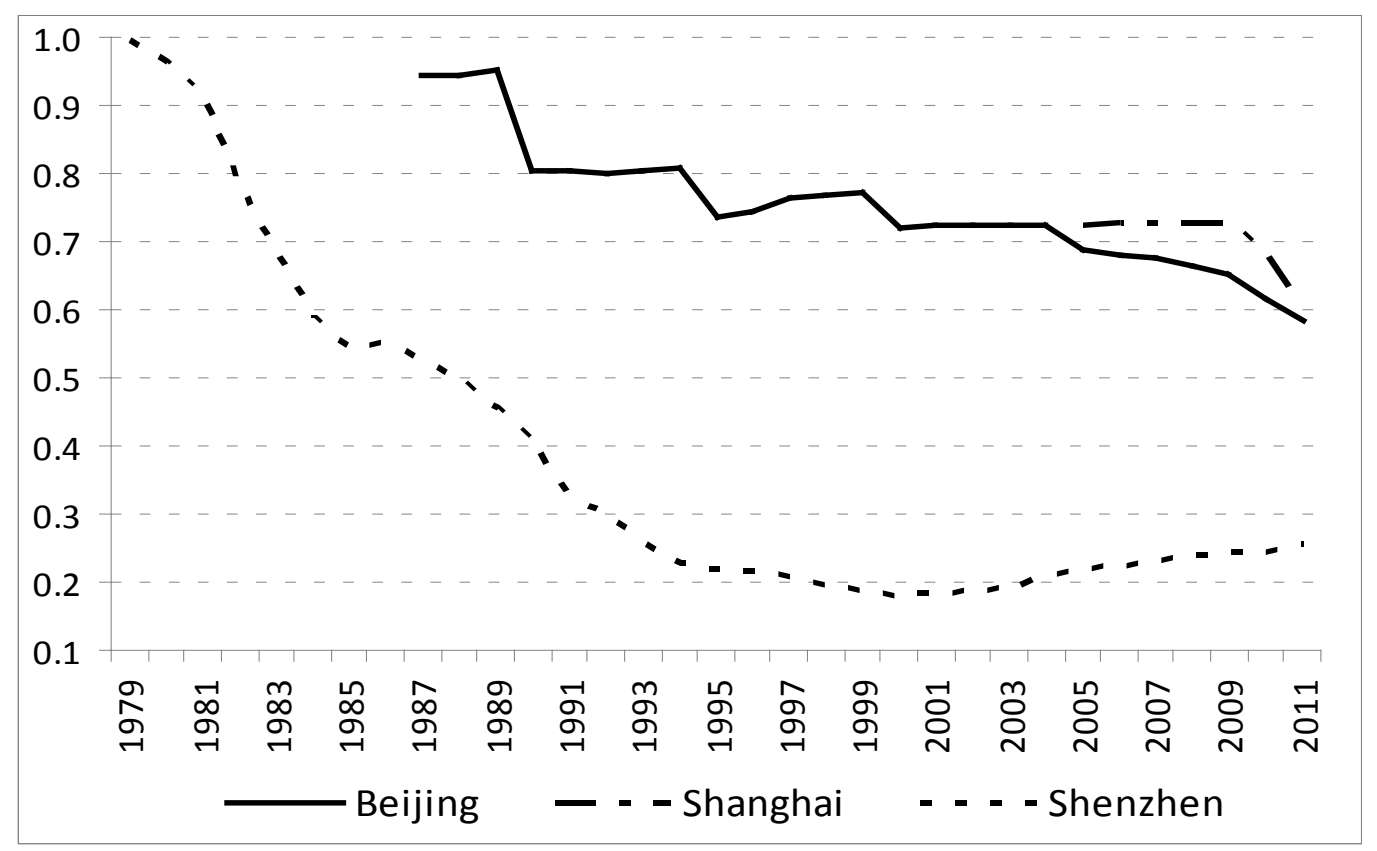

Source: National Statistical Bureau of China 
Table 1: Determinants of private consumption in China

\begin{tabular}{|l|c|c|c|c|}
\hline \multirow{2}{*}{} & \multicolumn{2}{|c|}{ Urban households } & \multicolumn{2}{c|}{ Migrant households } \\
\cline { 2 - 5 } & 2002 & 2007 & 2002 & 2007 \\
\hline Income & $0.842(0.007)$ & $0.766(0.008)$ & $0.862(0.010)$ & $0.828(0.010)$ \\
\hline Size & $0.020(0.005)$ & $0.051(0.006)$ & $0.060(0.006)$ & $0.060(0.008)$ \\
\hline Age & $0.015(0.002)$ & $0.014(0.003)$ & $0.008(0.005)$ & $0.023(0.004)$ \\
\hline $10^{*}$ Age^2 & $-0.001(0.000)$ & $-0.002(0.000)$ & $-0.001(0.000)$ & $-0.003(0.001)$ \\
\hline Education & $0.008(0.001)$ & & & $0.968(0.108)$ \\
\hline Constant & $0.902(0.086)$ & $1.858(0.114)$ & $0.782(0.110)$ & 4900 \\
\hline NOBS & 6830 & 4823 & 1997 & 0.384 \\
\hline Pseudo-R2 & 0.436 & 0.432 & 0.635 & \\
\hline
\end{tabular}

Note: Robust standard errors in parentheses. Private consumption (dependent) and income measured in logs. Empty cells represent zero coefficients, where the 0.1 significance level is used. 
Table 2: Income distribution and consumption ratios

Urban households

\begin{tabular}{|c|c|c|c|c|}
\hline & \multicolumn{2}{|c|}{2002} & \multicolumn{2}{c|}{2007} \\
\hline Quantile range & Income & APC & Income & APC \\
\hline$(Q 0.00-Q 0.10]$ & $(0-10.2]$ & $0.955(0.009)$ & $(0-20.0\}$ & $0.977(0.011)$ \\
\hline$(Q 0.10-Q 0.25]$ & $(10.2-14.4]$ & $0.913(0.009)$ & $(20.0-30.0]$ & $0.848(0.013)$ \\
\hline$(Q 0.25-Q 0.50]$ & $(14.4-20.9]$ & $0.886(0.006)$ & $(30.0-45.2]$ & $0.802(0.011)$ \\
\hline$(Q 0.50-Q 0.75]$ & $(20.9-30.1]$ & $0.840(0.007)$ & $(45.2-71.6]$ & $0.730(0.010)$ \\
\hline$(Q 0.75-Q 0.90]$ & $(30.1-42.0]$ & $0.799(0.008)$ & $(71.6-109.2]$ & $0.687(0.011)$ \\
\hline$(Q 0.90-Q 1.00]$ & $>42.0$ & $0.733(0.014)$ & $>109.2$ & $0.604(0.014)$ \\
\hline
\end{tabular}

Migrant households

\begin{tabular}{|l|c|c|c|c|}
\hline & \multicolumn{2}{|c|}{2002} & \multicolumn{2}{c|}{2007} \\
\hline Quantile range & Income & APC & Income & APC \\
\hline (Q0.00-Q0.10] & $(0-6.7]$ & $0.898(0.022)$ & $(0-10.2\}$ & $0.824(0.029)$ \\
\hline$(Q 0.10-Q 0.25]$ & $(6.7-9.6]$ & $0.864(0.010)$ & $(10.2-14.4]$ & $0.801(0.016)$ \\
\hline$(Q 0.25-Q 0.50]$ & $(9.6-14.3]$ & $0.826(0.008)$ & $(14.4-20.4]$ & $0.794(0.011)$ \\
\hline$(Q 0.50-Q 0.75]$ & $(14.3-21.1]$ & $0.772(0.008)$ & $(20.4-32.4]$ & $0.775(0.011)$ \\
\hline$(Q 0.75-Q 0.90]$ & $(21.1-29.4]$ & $0.756(0.013)$ & $(32.4-48.0]$ & $0.726(0.010)$ \\
\hline$(Q 0.90-Q 1.00]$ & $>29.4$ & $0.697(0.019)$ & $>48.0$ & $0.663(0.011)$ \\
\hline
\end{tabular}

Note: Standard errors in parentheses, income per annum in 1000 Yuan. APC is the average propensity to consume, i.e. household consumption expenditures divided by income. 
Table 3: Impact of the hukou on the average propensity to consume

A Households income $<=15,000$ in 2002 or $<=20,000$ Yuan in 2007

\begin{tabular}{|l|c|c|}
\hline & $2002(2963$ obs $)$ & $2007(2907$ obs $)$ \\
\hline Size & $0.031(0.005)$ & $0.061(0.009)$ \\
\hline Age & $0.008(0.002)$ & $0.011(0.003)$ \\
\hline $10^{*}$ Age^2 & $-0.001(0.000)$ & $-0.001(0.000)$ \\
\hline Education & $0.004(0.002)$ & $0.520(0.046)$ \\
\hline Constant & $0.541(0.057)$ & $0.146(0.023)$ \\
\hline Hukou & $0.051(0.011)$ & \\
\hline
\end{tabular}

B Households income $(15,000,30,000)$ in 2002 or $(20,000,50,000]$ Yuan in 2007

\begin{tabular}{|l|c|c|}
\hline & $2002(3955$ obs $)$ & 2007 (4330 obs) \\
\hline Size & $0.025(0.005)$ & $0.028(0.006)$ \\
\hline Age & $0.012(0.003)$ & $0.009(0.002)$ \\
\hline $10^{*}$ Age^2 & $-0.001(0.000)$ & $-0.001(0.000)$ \\
\hline Education & $0.005(0.001)$ & $0.523(0.038)$ \\
\hline Constant & $0.390(0.063)$ & $0.067(0.013)$ \\
\hline Hukou & $0.058(0.011)$ & \\
\hline
\end{tabular}

Note: Robust standard errors in parentheses. Empty cells represent zero coefficients, where the 0.1 significance level is used. 